\title{
Religious Education in Contemporary Ukraine: Some Courses of Study Analysed
}

\author{
JONATHAN SUTTON
}

The materials I am analysing in this article were gathered between 16 November and 16 December 1993 during field work for a Leeds University research project on the teaching of theology and religious studies in contemporary Russia and Ukraine. The principal objective of this project is 'to arrive at a detailed and informed understanding of the main developments in the teaching of theology and religious studies under the conditions of post-Soviet society'. ${ }^{1}$ This article aims to provide information about the content and structure of particular courses of study in the academic year 1993-4.

\section{Context: a Note on Current Legislation and on the Tenaciousness of Homo Sovieticus}

At the outset it is necessary to focus upon the distinction between secular, nondenominational teaching institutions and denominational ones. Not only are these respective types of institution different from one another in terms of their status, aims and ethos, but that very difference of status is accentuated and maintained by legislation currently in force in Ukraine. Article 6 of the Law on 'Freedom of Conscience and Religious Organisations', which dates from 23 April 1991, affirms the secular nature of the state system of education:

The state system of education in the Ukrainian Socialist Republic is separated from the church [religious organisations] and bears a secular character. Access to various types and levels of education is made available to citizens independently of their attitude towards religion ...

As can be seen, Article 6 perpetuates the principle of the separation of religion from education, which was of key importance in Soviet legislation. The reasons for the Ukrainian government's continued adherence to the principle of separation are varied and complex, and not the least of these may be inertia. The country is still experiencing a process of transition from an education system that actively promoted an atheistic understanding of the world. It is far from easy to gauge whether and to what extent the matter of separation is being disputed in government circles, but it is not the purpose of this article to record the attempts of churches or particular interest groups to sway the decision-makers in one or other direction. Rather, the Law on Freedom of Conscience and Religious Organisations is cited here as part of the context in which religious education is being planned and carried out. The following material, syllabuses of teaching institutions in Kiev, Khar'kiv, Donetsk and L'viv, shows the extent to which religious education is, at least de facto if not de jure, being carried out 
in secular teaching establishments, at primary, secondary and tertiary levels.

This is not a matter for great surprise, but certain features of the present state of transition are worthy of attention, and these will be commented upon in later sections. In particular, I will draw attention to the subject that now goes by the name of religiyevedeniye (or, in Ukrainian, religiyeznavstvo; both spellings are used in preference to religiovedeniye or religioznavstvo). I shall also have reason to comment upon the way that, in certain institutions, 'religious studies' as an academic subject has a reasonably promising future when pursued as part of 'cultural studies' or kul'turologiya. In certain cases these are the courses which replace the courses in 'foundations of Scientific Atheism' (osnovy nauchnogo ateizma), and the heading 'cultural studies' has made possible a quite considerable and rapid shift of emphasis which accords with the lecturer's true scholarly interests, expression of which is not only permitted but positively welcomed.

Of course, homo sovieticus is not immediately vanquished by means of the renaming of lecture courses. The next section devotes some space to courses of study still marked by the ethos of homo sovieticus.

Some insights into official thinking on the future of the Ukrainian system of education are afforded by a Resolution of the Cabinet of Ministers dating from 3 November 1993. This Resolution sets out the educational priorities and strategies for reform of the state system for the period 1994-2005. ${ }^{2}$ Religious education as such does not receive special attention. However, the spirit of the document, with its particular emphasis upon sound upbringing within the context of the family and its numerous references to the need for increasing awareness of national and cultural identity, could certainly accommodate religious education as an integral part of the general education of future generations in Ukraine.

The document in question, Resolution No. 896 (3 November 1993) of the Cabinet of Ministers of Ukraine, is entitled The State National Programme 'Education' ('Ukraine: the 21st Century'). ${ }^{3}$ Prominent in the list of 'the main ways of reforming education' (p. 3) is this:

To overcome the devaluation of universal human values and national nihilism and the separation of education from national roots.

Another item in the same list reads as follows:

To abandon authoritarian teaching methods which existed in the totalitarian state and caused the levelling down of natural talents and possibilities and interests of all participants in the education process. (also p. 3)

These reformist objectives are to be accompanied by 'the radical restructuring of management in education through democratisation and decentralisation'. (p. 3)

The need to achieve 'the creation of ethical values starting from early family-based education' is fully recognised in the Resolution (p. 7), and is linked with the need to promote unity or a sense of common purpose bet ween the family and the school (p. 9). It is very emphatically declared that parents and the family bear responsibility for the development and education of children (p. 12), instilling a sense of trust in them and thus providing a sound basis for their growth.

The final pages of the main body of the Resolution (pp. 42-4) pay particular attention to strengthening educational links with other countries. There are obvious practical benefits for Ukraine in aiming towards the mutual recognition of academic and professional qualifications and in working with agencies such as UNESCO, and one would expect the Ukrainian government to pursue such aims. However, this 
section of the document is noteworthy in one further respect: namely, it articulates a clear desire on the part of Ukrainians to belong fully to the family of European and other nations, bringing to an end the relative isolation they experienced during the years when they formed part of the Soviet Union.

\section{Courses of Study in Secular, Non-denominational Institutions}

In L'viv oblast' provisions exist for the training of teachers which allow new recruits to the profession to embark on teaching courses in Christian ethics, mainly (but not exclusively) in primary schools. The present arrangements also make it possible for teachers qualified in other subjects to train for one year to teach Christian ethics and take an examination, after which they are entitled to teach that subject. The year 1993 saw more than twenty successful candidates emerge from this training in L'viv oblast', and these are already working in schools.

A detailed syllabus for the course is presented here, listing the number of hours devoted to particular topics and indicating the levels at which the various topics are introduced, from fifth year to ninth year. Those who designed the syllabus sought to convey the nature of Christian ethics generally, underlining the importance of family values and the cultural context while trying to avoid involvement in the disputes that divide the Orthodox, Greek-Catholic and other communities in present-day Ukraine. Naturally, the syllabus has its critics, and there are those who doubt whether a course of this kind can be taught effectively by people who have received no more than one year of training in the subject. Staff with whom I spoke in the Education Department of the L'viv oblast' office underlined the point that the course they offer needs to be underpinned by sound ethical instruction within the family if schoolchildren are to derive optimum benefit from it. They also defended the course as representing at least a limited attempt to equip children in state schools with knowledge of central Christian precepts and their practical impact upon modern life and culture.

The structure of the 'Initial Educational Scheme on Christian Ethics' ('Oriyentovne navchal'ne planuvannya $z$ khrystyyans'koyi etyky'), approved in August 1993, is as follows.

\section{Year 5}

1. Subject 'Ethics'. Ethics - teaching about morals, about the system of life. [1 hour]

2. Faith and covenant. Faith and trust toward people, toward the Creator. Covenant - the law of life. God speaks to people. [1]

3. The two great commandments of love. Love - the effort towards genuine good for others. Self-love - the antithesis of love. [1]

4. The Commandments of God - the foundation of further well-being (dobrobyt), happiness in this life and eternal life. Sin - violation of the Commandments of God. [1]

5. Love - authentic respect to God and to people. [1]

6-7. The First Commandment of God: 'Thou shalt have no other gods but me' (Exodus 20:3). [2]

8-9. The Second Commandment of God: 'Thou shalt not take the name of the Lord thy God in vain' (Exodus 20:7). [2]

10-11. The Third Commandment of God: 'Remember the Sabbath Day, to keep it holy' (Exodus 20:8). [2] 
12. On rest, celebrations, and fasting. [1]

13-14. The Fourth Commandment of God: 'Honour thy father and thy mother, that it may be well with thee and that thy days may be long on the earth' (Exodus 20:12). [2]

15-16. The Fifth Commandment of God: 'Thou shalt not kill' (Exodus 20:13). [2]

17-18. The Sixth and Ninth Commandments of God: 'Thou shalt not commit adultery' (Exodus 20:14) and 'Thou shalt not covet they neighbour's wife' (Exodus 20:17). [2]

19-20. The Seventh and Ninth [sic] Commandments of God: 'Thou shalt not steal' (Exodus 20:15) and 'Thou shalt not covet thy neighbour's goods' (Exodus 20:17). [2]

21-22. The Eighth Commandment of God: 'Thou shalt not bear false witness against thy neighbour' (Exodus 20:16). [2]

23-24. The principal sins and their opposing virtues. [2]

25-26. Repentance. Confession. The examination of conscience. [2]

27. Christian charity. [1]

28. Christian love. [1]

29. Strong, active faith. What will a course of ethics do for us? [1]

30. Special lesson. [1]

31-32. Generalised lessons. [1]

Thirty-one hours in total.

\section{Year 6}

1. Introduction. Law. Divine Law, state law, church law. The universal moral law: to do good and avoid evil. [1]

2. Holy Scripture (the Bible) - the history of salvation of the human race. [1]

3. The Old Testament - God speaks to the people through righteous people, through kings, through prophets. [1]

4. The New Testament - a brief survey. [1]

5. The Gospel - the Good News. History of the life of Jesus Christ. [1]

6. The significance of a parable as a literary genre. Examples. The parables of Jesus and their particular characteristics. [1]

7. The importance of the Word of God. The parable of the sower. The parable of the tares. [1]

8. The spreading of the Word of God over the earth. The parable of the mustard seed. [1]

9. The most important ability to choose in life. Faith in the victory of good over evil. The parable of the treasure and the pearl. The parable of the unknown. [1]

10. Christ - the Good Shepherd. The parable of the lost sheep. [1]

11. The essence of repentance and conversion. Examination of conscience. The parable of the prodigal son. [1]

12. Confession. The five conditions of a good confession. How to go to confession. [2]

13. Prayer - to speak with God. How is it necessary to pray? The parable of the publican and the pharisee. [1]

14. Sympathy, charity, alms-giving. Love - the will to do good. The parable of the good Samaritan. [1]

15. God's call and the response to it. The human person is called to do good. The 
parable of the wedding feast. [1]

16. The role of wealth in the life of the human person. Reward and punishment. The parable of the rich man and Lazarus. [1]

17. The ability to love and the ability to forgive. The parable of the unmerciful debtor. [1]

18. Remuneration for labour. The fulfilment of one's word and agreement. The parable of the labourers in the vineyard. [1]

19. Reason - the gift of God. The parable of the nine virgins. [1]

20. Talent. Abilities. Understanding of responsibility. The parable of the talents. [1]

21. Hope in God's mercy. The parable of the unjust judge. [1]

22. The path to good or evil. Temptation. Sin. Responsibility. The parable of the vine-dressers. [1]

23. Respect for parents. Disobedience - the refusal of love. The parable of the two sons. [1]

24. Divine mercy and unlimited patience. The parable of the fruitless fig tree. [1]

25. The chief sins and their opposing virtues. The parable of the rich man. [1]

26. Christian morals - the structure of a righteous life. [1]

27. The young generation - the future of Ukraine. The parable of the candle on the candlestick. [1]

28. Heaven and hell. Punishment and reward. The parable of the sheep and the goats. [1]

29. Christ teaches about life with God and people. Gratitude - the expression of human dignity. The healing of the ten lepers. [1]

30. The right of children to their own convictions. Jesus and children. Jesus blesses children. [1]

31. The desire to know Christ. The material and spiritual world of the human person. Jesus and the rich young man. Jesus in the house of Zacchaeus. [1]

32-33. Moral bases of Christianity. Jesus Christ - the ideal of human perfection. Jesus Christ's Sermon on the Mount. [2]

34. Generalised lesson. [1]

Thirty-five hours in total.

\section{Year 7}

1. Introduction. Fundamental categories of ethics (good, human dignity, virtue, conscience, happiness) relating to law, the Creator, one's neighbour, and oneself. [1]

2. The understanding of good and evil. The Holy Archangel Michael. [1]

3. The understanding of hope. Saint Anna. [1]

4. (a) The ethical category of holiness. (b) The Virgin Mary as the ideal of virginity and motherhood. [1]

5. (a) The understanding of responsibility. (b) Work as a component element of holiness. Saint Joseph. [1]

6. The understanding of freedom. To be a human person means to be free. Saint John the Baptist. [1]

7. Human weakness. Betrayal and remorse. Strengthening of the will, of character. The Holy Apostle Peter. [1]

8. Vocation. The nobility of the soul. The mission of the human person in the state. The Holy Apostle Andrew the First-Called. [1] 
9. The right to err. To live according to conscience - the chief life principle of the human person. The Holy Apostle Paul. [1]

10. Sincerity and fidelity to one's own convictions. The Holy Protomartyr and Archdeacon Stephen. [1]

11. Friendship, sincerity and fidelity. Saint John the Theologian. [1]

12. Love and sacrifice. The vocation of a mother. The Holy Martyrs Faith, Hope, Charity and their mother Sophia. [1]

13. The understanding of family and social comfort. Self-perfection. Saint Anthony the Great. [1]

14. The best traits of a youth. Chivalry. No compromise with evil. Saint George the Victorious. [1]

15. Charity. The spirit of unselfishness. Saint Nicholas the Wonderworker. [1]

16. The thirst for knowledge as an ethical value. Saint Basil the Great. [1]

17. Humanism. The pluralism of thought. Saint Gregory Nazianzen. [1]

18. The divine gift of speech. Talents. Saint John Chrysostom. [1]

19. The power of will. Stability in one's convictions. Saint Demetrius the Great Martyr. [1]

20. Religious freedom in the state. The importance of the understanding of the truths of Christianity by statesmen. Saints Constantine and Helen. [1]

21. The path to virtuous life. Saint Ambrose. [1]

22. The role of the human person in God's plan. The power of prayer. Saint Augustine. [1]

23. National culture. Church culture as a cultural value. Saint John of Damascus. [1]

24. Ethical respect for the native language while entering into world culture. Saints Cyril and Methodius, apostles and enlighteners of the Slavs. [1]

25. The importance of spiritual and material harmony in the life of the human person. Thomas Aquinas. [1]

26. The moment of personal choice. The importance of standing on truth, and not with the authorities. Thomas More. [1]

27. A struggler for Christian unity - the Holy Martyr Iosafat Kuntsevich. [1]

28. The ideal of the Christian woman. Joan of Arc. [1]

29. Repentance and conversion. Mary of Egypt. [1]

30. The ecology of the spiritual world of the young person. Don Bosco. [1]

31. The enrichment of the human race with the ethical values of Christianity. The Christian alternative: 'the civilisation of love'. Maximilian Kolbe - a contemporary saint. [1]

32-33. A garland of Ukrainian saints. The veneration of Ukrainian Saints: Volodymyr the Great, Princess Ol'ha, the martyrs Borys and Hlib, Yefrosynya, Antoni and Teodosi of the Caves. [2]

34. Generalised lesson. [1]

Thirty-four hours in total.

\section{Year 8}

First Semester

1. Subject 'Ethics'. Ethics - moral teaching, systematic rules of life. Fundamental categories of ethics. [1]

2. Faith and covenants. Divine, ecclesiastical, state laws. [1]

3. The two chief commandments of love. Christian truthfulness. [1] 
4. What is sin? Sin - disrespect for God and people. True respect for God and people - the foundation of love. [1]

5. Holy Scripture (the Bible) - the history of human salvation, the inexhaustible source of our faith and morals. [1]

6. 'I believe in One God'. The parable of the sower. The First Commandment of God. [1]

7. 'I Am Who Am' (Exodus 3:14). The parable of the publican and the pharisee. The Second Commandment of God. [1]

8. The Sabbath. The healing of the man with the withered arm. The Third Commandment of God. [1]

9. Obligations of parents and children. The family - the first school. The parable of the prodigal son. The Fourth Commandment of God. [1]

10. Respect for one's own life and the lives of others. The parable of the vinedressers. The Fifth Commandment of God. [1]

11. Honour. Purity of body and thought. Jesus and the Samaritan woman. The Sixth and Ninth Commandments of God. [1]

12. The right of the human person to property. The parable of the rich man and Lazarus. The Seventh and Tenth Commandments of God. [1]

13. Talent - the gift of God. Good name, honour, glory. The parable of the talents. The Eighth Commandment of God. [1]

14. 'God is love' (I John 4:16). Love - the desire of good for others. Divine virtues, moral virtues. The parable of the good Samaritan. [1]

15. Happiness. How to become happy. The Sermon on the Mount. The Beatitudes. [1]

16. Repentance. Examination of conscience. Contrition - the foundation of repentance. [1]

17. God's Commandments - the structure of salvation and of the happiness of the human person. Christ's parables - the source of religious understanding and moral truths. [1]

Seventeen hours in total.

\section{Second Semester}

1. Christianity and culture. [1]

2. The culture of relations, as an element of general human culture. [1]

3. Etiquette of behaviour. Can we be together? [1]

4. The ethics of behaviour in different circumstances and different places. [1]

5. Gifts. Signs of regard. The symbolism of flowers. [1]

6. In the concert hall, the theatre, the cinema. [1]

7. Telephone conversation. Correspondence. [1]

8. Travel. [1]

9. Dance. [1]

10-11. Visiting. We receive guests; we are guests. Table manners. [2]

12-13. Family celebrations: Christmas, Easter, anniversaries, birthdays. The spirituality ${ }^{4}$ of family celebrations. [2]

14. Baptisms. Godparents [1]

15. Weddings. [1]

16. Funerals. [1]

17. Conduct in church, at divine services and at holy places. [1]

Seventeen hours in total. 


\section{Year 9}

First Semester

Identical to the First Semester for Year 8.

\section{Second Semester}

1. The moral values of friendship, romance, the family. Camaraderie. The family and marriage. [1]

2. Youth - the moment of fundamental choice (profession and partner). [1]

3-4. Physiological and psychological aspects of the organic development of a boy and a girl (separate classes for boys and girls). [2]

5. Love as the highest spirituality. ${ }^{4}$ First love. The problem of engagement. [1]

6-7. Conversations with boys and girls about the appropriate relationships between boys and girls. [2]

8. Relationships before marriage. [1]

9. The pagan understanding of the family. [1]

10. The Christian view of the family. [1]

11. The Christian understanding of professions as vocations. [1]

12-13. Different forms of moral enslavement of the human person. [2]

14. The culture of spending free time. [1]

15. The 'Song of Songs' as the celebration of spiritual love. [1]

16. Beauty and style. The spirituality ${ }^{4}$ of sport. Dances as expressions of love of neighbour. [1]

17. Married life and its significance. The communal meaning of marriage. [1]

Seventeen hours in total.

Turning to the sphere of higher education, there now follows the syllabus for a course on ethics at Ivan Franko University in L'viv. Ethics is one of three major subjects taught in the Department of the Theory and History of Culture, the other two courses being aesthetics and cultural history. This very active department offers lecture courses for students right across the faculty divisions. Students concentrating mainly on natural sciences attend 36 hours of lectures on ethics and aesthetics combined, while students in the humanities will attend 36 hours of lectures on each of these subjects. These courses are offered to students in the Law Department (172), History Department (125), Foreign Languages Department (100), Economics Department (120), Journalism Department (75), International Relations Department (50) and others. ${ }^{5}$ At Ivan Franko University the 'cultural history' course of 72 hours of lectures includes a 'history of religion' component of at least 18 hours. It should also be noted that half of the entire course is devoted specifically to the study of Ukrainian culture.

The Department of the Theory and History of Culture also has a scheme of postgraduate study in three specific areas, namely the sociology of culture, ethics and the history of religion. Staff are at present engaged in the preparation of a textbook on the history of Ukrainian culture.

The undergraduate course on ethics is taught by Stanislav Mikhailovich Shendrik, who is also supervising a postgraduate student working on the moral philosophy of Vladimir Solov'yev. In 1992-3 he taught an optional course on Russian and Ukrainian philosophy, and may do so again in future years.

The structure of the course on ethics in the Department of the Theory and History of Culture at Ivan Franko University in 1993-4 is as follows. 


\section{Lectures}

1. The subject-matter and tasks of ethics. [2 hours]

2. The principal tendencies in the historical development of ethical thought in the world. [4]

3. The principal stages and tendencies in the development of ethical thought in Ukraine. [4]

4. The notion of moral philosophy. [2]

5. The origin and historical development of moral philosophy. [2]

6. Mankind's higher moral values. [2]

7. Moral choice and man's orientation towards values. [2]

8. Moral philosophy and national culture. [2]

9. The ethics of family life. [2]

10. The moral culture of communication. Ethics and etiquette. [2]

11. The moral content of friendship and love. [2]

12. Moral philosophy and ecology. [2]

13. Moral education and the self-perfection of the individual. [2]

Thirty hours in total.

\section{Seminars}

1. Ethics as a theory of moral philosophy. [2]

2. The moral life of mankind. (2)

3. Moral philosophy and national culture. [2]

Six hours in total.

Dr Shendrik's course of religious studies (religiyeznavstvo) is structured as follows:

\section{Lectures}

1. The subject-matter of 'religious studies'. [2]

2. Religion as a spiritual phenomenon. [2]

3. The historical types of religion. [6]

4. Christianity as a world religion. [4]

5. The principal tendencies in Christianity. [10]

6. Religion and spiritual culture. [4]

7. Freedom of conscience: historical and contemporary aspects. [2]

Thirty hours in total

\section{Seminars}

1. The Bible as a prime embodiment of history and world culture. [2]

2. Christianity in Ukraine: historical and contemporary aspects. [2]

3. Freedom of conscience as the spiritual sovereignty of man. [2]

Six hours in total.

As can be seen, the total number of hours devoted to the above course is 36 hours, covering lectures and seminars together. 
At Khar'kiv State University the 'history of religion' course is taught by Dr Mikhail Aronovich Blyumenkrantz. There, as in L'viv, the course is available to humanities students and science students alike, but the numbers of those attending lectures are generally rather modest. Dr Blyumenkrantz finds that very few students wish to go beyond the basic introductory level at which he has to pitch his lectures.

Dr Blyumenkrantz himself is wholly committed to research and writing in the field of cultural studies (kul'turologiya) or what we might call 'the history of ideas'. The syllabus of his course is but a pale reflection of his scholarly interests, among which the ideas of Dostoyevsky and of the contemporary scholar Grigori S. Pomerants figure prominently. ${ }^{6} \mathrm{He}$ is concerned to investigate the aesthetics and status of legend as a genre, the charisma of political leaders and the myth-making that attaches to them, and many related issues which draw on anthropology, political science and theology.

The structure of the course on the history of world religion at Khar'kiv State University in 1993-4 is as follows.

\section{Lectures}

1. The sources of religion. [2 hours]

2. The religious worldview and the problem of knowledge of the world. [2]

3. Religious awareness at the stage of ancient culture. [2]

4. The religion of Ancient Egypt. [2]

5. Religious conceptions among the inhabitants of ancient Mesopotamia. [2]

6. Zoroastrianism. [2]

7. Religion in Ancient Greece. [2]

8. Traditional and non-traditional religious teachings in India. [6]

9. Religious teachings in Ancient China and Japan. [6]

10. Judaism, its past and present. [6]

11. Islam. [6]

12. Christianity. [10]

13. Contemporary religious reflection in the West. [4]

14. Russian religious-philosophical thought. [4]

15. Religion and ideology. [6]

Sixty-two hours in total.

At the State Institute of Culture in Khar'kiv the lecture course on religious studies is given by Dr Vasili Grigor'yevich Shadursky. This course is studied by all students at the Institute of Culture, with further optional courses being offered in Foundations of Theology and Foundations of Theosophy. The content of Dr Shadursky's religious studies course was slightly altered between the academic years of 1992-3 and 1993-4. The following is a list of themes covered in the 1992-3 syllabus, with fuller details of Theme 10, which was omitted from the current syllabus.

1. Religious studies as an academic subject.

2. Religion as a social phenomenon.

3. The origin of religion and its historical forms.

4. The religions of the East: their history and teachings.

5. Judaism.

6. Christianity: its emergence and development.

7. The world as depicted in religion.

8. The being of man and the world as presented in religion. 
9. Religion: its place in the spiritual life of society.

10. Free thought and religion.

11. Religion in the contemporary world.

12. Religion in the context of the history of the Ukrainian people.

13. Religion and churches in process in twentieth-century Ukraine.

14. The realisation of freedom of conscience in democratic Ukraine.

\section{Theme 10}

\section{Free thought and religion}

\section{(a) Free thought as an element in spiritual culture}

Forms of free thought in relation to religion: heresy, anticlericalism, religious indifference, scepticism, pantheism, deism, atheism.

\section{(b) Free thought in artistic culture 7}

The struggle against God (bogoborchestvo) and anticlericalism in world folklore; elements of free thought in popular art; the expression of free thought in the drama, poetry and art of ancient Greece and Rome; religious indifference and anticlericalism in the artistic culture of the Middle Ages; humanism in the art and literature of the Renaissance and the modern age; the problem of man in Ukrainian artistic culture.

\section{(c) Free thought in scientific knowledge}

The emergence of natural science, and the process of its liberation from theology; the formation of the scientific conception of the world, and the departure from religious conceptions of natural phenomena; the appearance of evolution-based ideas about the origin of man; attempts to provide non-religious explanations of social phenomena, the departure from religious interpretations of history, and non-religious evaluations of the role of particular figures in history.

(d) Free thought in theology and philosophy

Atheism in ancient times (Democritus, Epicurus, Lucretius); philosophical explanations of the origin of religion; theological heresies of the Middle Ages; forms of heresy in the world religions; heresies in ancient Russia; theories of the dual nature of truth (Ibn-Rushd); the rationalist critique of authoritarianism and dogmatism of the world religions, and contradictions in accounts of religious faith (Abelard).

(e) Scepticism

Scepticism regarding the reliability of the grounds of truth of the religions (Sextus Empiricus, Bayle, Montaigne); pantheism and its various forms; particular characteristics of the pantheism of Giordano Bruno and of Spinoza; deism as a form of liberation from religion (Hobbes, Voltaire, M. V. Lomonosov); the development of positive knowledge about religion undertaken by idealist philosophers (Hume, Kant, Hegel).

\section{(f) Atheism in the modern world}

Thinkers of the Enlightenment and French materialist philosophers of the eighteenth century; the essence, origin and functions of religion; the atheism of Feuerbach; the atheism of Ukrainian thinkers including T. G. Shevchenko and Ivan Franko; ${ }^{8}$ contemporary free thought and atheism in the culture of the West, including Bertrand Russell and J.-P. Sartre.

It should be mentioned that of all the themes described in the Institute of Culture's syllabus for religious studies, only Theme 10 refers to individual thinkers by name. The 
description of other themes in the course is confined to the listing of general topics covered.

The reader may notice that the religious studies course at Ivan Franko University and the course offered at Khar'kiv's State Institute of Culture both end with lectures on freedom of conscience. This topic also features in the religious studies course of the Kiev-Mohyla Academy, full details of which are presented below. ${ }^{9}$ The title of the relevant lecture at the Kiev-Mohyla Academy is 'The realisation of freedom of conscience in democratic Ukraine' (Lecture 28). The current legislation of Ukraine provides for freedom of conscience, and one should, at this point, consider the inclusion of this topic in religious studies courses regardless of the personal beliefs of the lecturers teaching the courses in particular institutions.

The subject of freedom of conscience could, naturally, be approached in a variety of ways, some of which could lead to quite fruitful reflection on the uses of freedom, the exploration of ways to reconcile religious ideas and notions of civic responsibility, and so forth. Pursued in a spirit of tolerant and open-ended discussion, this topic could prove a very valuable element in any religious studies course, in Ukraine or elsewhere. However, given the former legislation and conditions of Soviet society and the difficulties of transition from the Soviet model of education, the presentation of the issue of freedom of conscience poses problems. In the Russian Federation people have already learnt, to their cost, how freedom of belief and freedom of expression of belief give scope to organisations like Pamyat' and other undemocratic movements. One should recall that in the specific context of religious belief, Article 3 of the 1990 Law on Freedom of Conscience and Religion affirms the following:

each citizen independently decides his own attitude towards religion and enjoys the right to confess any religion either alone or jointly with others, or not to confess any religion [italics added], and to express and spread convictions associated with his attitude towards religion.

In Soviet society atheists were never in danger of having that particular right infringed. Subsequently, though, the openness and, at times, apparent dominance of expression of religious views have brought forth a sense of defensiveness among atheists. With the 'religious' outlook in the ascendant, they have experienced personal and professional difficulties which should not be minimised. It is unlikely that the majority of lecturers teaching courses on 'the foundations of Scientific Atheism' expected the process of shedding Marxist-Leninist ideology, which began in earnest after the Millennium celebrations of Summer 1988, to gain such rapid momentum thereafter. ${ }^{10}$ In any case, it would not be surprising if a significant proportion of those lecturers who now find themselves working in departments called 'Department of Religious Studies' felt a need to defend the atheist position. My contention here is that the inclusion of 'freedom of conscience' as a topic in religious studies courses does give scope for 'special pleading' for the atheist case. I say this without in any way disputing the appropriateness of including the topic in religious studies courses in general, nor do I argue for its exclusion from such courses as have been established in republics of the former Soviet Union. The benefits of discussing the topic, for students and lecturers themselves and for the promotion of a truly pluralistic society, are plain to understand, and these far outweigh any possible misuse of the topic by those seeking to steer academic discourse back towards the false 'certainties' with which they themselves feel most comfortable.

The Kiev-Mohyla Academy ${ }^{11}$ offers a 78-hour course of lectures on religious studies, under 34 topic headings, together with a 13-part seminar series. It also offers 
a combined lecture and seminar course entitled 'the history and foundations of Christianity', with 36 hours devoted to lectures and 12 hours to seminars. A further 12-part seminar series (prefaced by two lectures) on the Bible is also available at the Academy. The structure of these courses in 1993-4 is as follows.

\section{Lectures}

1. Religious studies as an academic subject. [2 hours]

Section 1: Religion as a spiritual phenomenon

2. Religion as the subject-matter of religious studies. [2]

3. The structure of religious beliefs. [2]

4. The world as depicted by religion. [2]

5. The religious conception of human existence. [2]

6. Religion as a moral ideal. [2]

7. Science in the context of the religious worldview. [2]

8. The mutual interrelationship of art and religion. [2]

\section{Section 2: History of religion}

9. Religion as a socio-historical phenomenon. [2]

10. The origins of religion. [2]

11. Tribal religions. [2]

12. Pre-Christian beliefs of Ukrainians. [2]

13. Religion and ethnicity. National and state religions. [2]

14. Judaism: the national religion of the Jews. [2]

15. World religions. Buddhism as a world religion. [2]

16. The origins and spread of Christianity. [2]

17. The Bible in the context of world religions. [2]

18. The basic content of Christian belief. [2]

19. The main branches of Christianity. [6]

20. Islam as a world religion. [2]

21. Mysticism in the past and at present. [2]

22. Religions of the New Age. [4]

23. The destiny of Christian theology. [2]

24. Religion in the modern world. [2]

25. The spread of religion in geographical terms. [2]

\section{Section 3: Religion in Ukraine}

26. Religious expressions of the spiritual world of the Ukrainians. [2]

27. Christianity in the context of the history and culture of the Ukrainian people. [4]

28. The realisation of freedom of conscience in democratic Ukraine. [2]

29. Religion and the church in the national and spiritual rebirth of Ukraine. [2]

Section 4: The history and present situation of religious studies

30. The stages of the history and main directions of religious studies. [4]

31. The historical forms of the critical approach to religion. [2] 
32. Analysis of modern religious studies as an academic discipline. [2]

33. Present situation and future perspectives of religious studies in Ukraine. [2]

34. Methodological principles, methods and categories of religious studies as an academic discipline. [2]

\section{Seminars}

Theme 1: The definition and structure of religion

(a) Basic approaches in the interpretation of the phenomenon of religion.

(b) The nature and definition of religion.

(c) The structural elements of religion.

Theme 2: Philosophical explanations of the phenomenon of religion

(a) Philosophy and religion in the context of their nature and genesis.

(b) Philosophy of religion as a branch of religious studies. Main directions of modern philosophy of religion.

(c) Particular gnoseological characteristics of religious consciousness. Irrationality and religion.

(d) Main types of modern philosophical teachings concerning God.

Theme 3: Anthropological interpretation of religion

(a) Man's attitude to God - the fundamental problem of the religious worldview.

(b) The image of man in Christian anthropology. The Divine Purpose and freedom of the individual.

(c) Theoretical programmes of modern philosophical and religious anthropology.

Theme 4: Social and psychological characteristics of religion

(a) The psychology of religion as an area of religious studies. Its main directions and schools.

(b) The particular characteristics of religious imagination and feelings. Religious experience as a main category of the psychology of religion.

(c) The nature and structure of religious belief.

(d) Psychological functions of religion. Religion and the socio-psychological balance of the individual.

Theme 5: The socio-historical nature of religion

(a) Particular characteristics of religion as a socio-historical phenomenon. The social characteristics of religion.

(b) The social functions of religion.

(c) Religion in world history. Norms of the historical development of religion.

(d) The social doctrine of Christianity: its history and evolution.

Theme 6: Religion in the context of culture

(a) Spirituality as a basic notion in the understanding of the nature of culture and religion. The place of religion in the system of spiritual culture. 
(b) The religious and theological conception of culture. The main types of religious explanation of culture.

(c) Cultural progress and religion.

Theme 7: Religion and politics

(a) Forms of mutual interrelationship between religion and politics. Ways and forms in which religion and the church are used in political life.

(b) The notion of institutionalisation as the basis of analysis of the mutual interrelationship of religion and politics. Functions of the church in society.

(c) The evolution of socio-political orientations and activeness of religious organisations. Ideology and policies of modern clericalism.

(d) Global problems of modern-day life and the church.

Theme 8: The moral potential of religion

(a) Religion and morality as spheres of the human spirit. The special characteristics of religious morality.

(b) The ethical aspect of religion. The moral principles of the Ten Commandments.

(c) Moral values of Christianity. The ethics of the Sermon on the Mount.

Theme 9: Modern theology and science

(a) Science and religion as spheres of spirituality.

(b) The special characteristics of scientific and theological reflection. Theological interpretation of science.

(c) The world as depicted by science and by religion. An attempt by modern theology to reconcile these views of the world.

Theme 10: Religion and art

(a) Religion and art as spheres of human spirituality. Their origins and mutual interrelationship.

(b) The problem of creative discovery and realisation of the spirit in religion and art.

(c) Special characteristics of religious art.

(d) World religions and art.

Theme 11: Religion in the spiritual life of the Ukrainian people

(a) The Ukrainian mentality.

(b) The interrelationship of Ukrainian mentality and the religious outlook. Religious expressions of Ukrainian spirituality.

(c) Religion as an element of the development of Ukrainian culture.

Theme 12: The modern situation of religion and the religious outlook in Ukraine

(a) The ideological indoctrination of society and its influence upon the religious outlook during the Soviet period of Ukraine's history.

(b) Institutional processes in Christian churches in Ukraine and the problem of interconfessional relations. 
(c) Religious rebirth: special characteristics and tendencies. The problem of a national church in Ukraine.

Theme 13: Religion in the modern world

(a) Religious crises and secular processes in society: their influence upon the future of religious consciousness.

(b) Socio-political and theoretical bases for confessional differences. The growth of the influence of new religions.

(c) The evolution of socio-political tendencies and activities of religious organisations.

(d) The integration of modern theology with social and philosophical thought. Various forms of modernised religion.

The structure of the course on 'the history and foundations of Christianity' at the Kiev-Mohyla Academy, 1993-4 (for second-year students) is as follows.

\section{Lectures}

1. The age of the formation of Christianity: historical, socio-economic and psychological characteristics. [2 hours]

2. Christianity of the early centuries. [2]

3. The spread of Christianity and the establishment of the church and its bishops. [2]

4. Christianity in the period of the Councils, fourth to seventh centuries. The separate directions taken by the Christian confessions, fifth to eleventh centuries. [2]

5. The principal content of the teachings, liturgy and organisation of Christianity as a world religion. [4]

6. Orthodoxy and its particular characteristics. Orthodoxy in the history of Ukraine. [4]

7. Catholicism: particular characteristics of its teachings, practice and historical evolution. [4]

8. Catholicism and Ukraine. [2]

9. The emergence and spread of Protestantism. [4]

10. Protestantism in Ukraine. [2]

11. Christian confessions in our country under the conditions of the socialist experiment. [2]

12. Christianity in independent Ukraine and in the modern world. [2]

13. The Bible: a general overview. [4]

\section{Seminars}

1. The place of the Old Testament in the culture of the ancient world. The world of the Old Testament. [2]

2. The Pentateuch of Moses as the basis for the Old Testament. [2]

3. The 'historical books': the foundations of 'historical consciousness' of the Old Testament. [2]

4. The prophetic movement and the Books of the Prophets. [2]

5. The Books of Teachings ${ }^{12}$ of the Old Testament. [2]

6. The Old Testament as a source of religious and moral tradition. [2] 
The structure of the course of study on the Bible at the Kiev-Mohyla Academy in $1993-4$ is as follows.

\section{Lectures}

1. The history of Biblical research. [2 hours]

2. The New Testament as the source of Christian philosophical and moral tradition. [2]

\section{Seminars}

1. The principal stages of the history of the books of the New Testament. [2]

2. The apocryphal literature of the first Christians. [2]

3. The Gospels and the Acts of the Apostles as historical books of the New Testament. [2]

4. Same as Seminar 3. [2]

5. Christian teachings in the Epistles of the Holy Apostles. [2]

6. The Revelation of John the Theologian - the imitation and development of Old Testament eschatology. [2]

7. The person of Jesus Christ as the founder of the Christian Church. [2]

8. Christ: the symbolic centre of the New Testament. [2]

9. The moral content of the New Testament. [2]

10. Jesus Christ and the Apostolic Church. [2]

11. Holy Scripture and holy tradition. [2]

12. Biblical studies as an area of knowledge in religious studies. [2]

At Donetsk State University a prominent member of the Religious Studies Department is Professor Vyacheslav Ivanovich Boyarintsev. Although he did not provide a copy of the syllabus he teaches, he gave very generously of his time and readily discussed a whole range of issues related to it. In particular, he went out of his way to arrange a meeting with Archimandrite Guri (Kuz'menko), diocesan secretary of the Orthodox diocese of Donetsk. ${ }^{13}$ The library at Professor Boyarintsev's home is well stocked with works on theology, and his knowledge of German gives him good access to critical and exegetical literature of the Protestant and Catholic traditions. A friendship of many years with a scholar attached to the Oriental Section of the Gregorian University in Rome allows him to exchange ideas on developments in the Catholic world. At the time of my encounter with Professor Boyarintsev (beginning of December 1993), he was studying the text of the Pope's new encyclical Veritatis splendor (in German translation). His approach was marked by genuine interest and also by a sense of duty towards his students. He seemed anxious to keep well informed about such matters as the encyclical and, generally, gave the impression of being a conscientious teacher who saw it as his task to convey to his students the nature of the various religious denominations, the principal ideas of influential theologians and the controversies that exist among them. This is even more true of Dr Blyumenkrantz of Khar'kiv State University, whose lectures on religion in the West treat the ideas of the following: Gilson, Maritain, Barth, Tillich, Niebuhr, Bultmann, Rahner, Guardini, Teilhard de Chardin, Thomas Merton, Metropolitan Anthony of Sourozh on prayer, Bonhoeffer and, finally, Kierkegaard and Camus on the absurd.

Any fundamental transition in society's structure and belief systems will yield a bewildering quantity of anomalies and departures from recognisable modes of 
thought and feeling. In an area as sensitive as religion, the anomalies and resultant shifts of perception can be both painful and highly conducive to conflict, a point that is borne out by experience in various republics of the former Soviet Union. It is the competing forms of nationalism which tend to capture newspaper headlines, but there can be little doubt that, in a less public way, people in the world of education are concerned to promote their own particular values. They do this, largely, by devising courses of study which reflect those values. Generally, the language in universities and other teaching institutions may suggest moderation and a relative lack of concern with ideologies in conflict; yet one still comes away with the feeling that there remains 'unfinished business' between atheists and those scholars whose fundamental outlook is 'religious'. And, for a very considerable period of time to come, the particular fields of sociology of religion and psychology of religion will afford opportunities to pursue a deterministic and fundamentally hostile approach to the subject of religion.

Religiyeznavstvo, the Ukrainian word currently being used to denote 'religious studies' (or its Russian equivalent religiyevedeniye), appears in the name of departments whose previous main purpose had been to teach 'scientific atheism'. Textbooks for such courses were published in large print-runs $\left(200,000\right.$ copies) as recently as $1988 .{ }^{14} \mathrm{Staff}$ at Ivan Franko University confirmed that the 'foundations of Scientific Atheism' course was being taught at their institution up until 1990, after which there followed a lengthy period of uncertainty about the nature and structure of courses to be taught.

Scholars from two higher education establishments informed me that the next development was that in May 1993, or at least in time for the present academic year 1993-4, the Ministry of Education of Ukraine required all students in higher education establishments (vuzy) to attend lecture courses either in religious studies or in the history of religion. Professor Anatoli Nikolayevich Kolodny, Head of the Department of Religious Studies at the Institute of Philosophy of the Academy of Sciences of Ukraine, believes that the professional association of lecturers in this field was, largely, instrumental in bringing about this decision at government level. ${ }^{15}$ Subsequent enquiries addressed to the Ministry of Education itself revealed that a final decision about making such courses compulsory had not yet been reached (at the time of writing, February 1994). It would appear, then, that where individual teaching institutions make these courses compulsory, they are actually anticipating the final outcome of deliberations within the Ministry of Education.

It is possible that, with the passage of time, the Ministry of Education may itself be swayed by the eventual predominance of compulsory courses, the status of which is being successfully secured by lecturers in particular institutions skilled in 'defending their own corner'. If that does indeed prove to be the case, it would reflect the extent to which improvisation plays a role in the organisation of religious studies departments at present. There can be little doubt that lecturers' research interests and awareness of students' preferences now come into the picture in a way that they barely could in the highly centralised Soviet system of education. ${ }^{16}$ I was given to understand that, in the wake of the failed coup of August 1991, the new academic year 1991-2 saw the appointment of lecturers highly sympathetic to religion who would probably not have secured lectureships in other times or circumstances - another instance of adapting to the moment. (In private correspondence of January this year, my source for this information notes the renewed ascendancy of the former adherents of the Communist Party and comments upon his own sense of isolation and vulnerability within the department where he is employed.)

At present the approach to the subject in Ukraine is characterised by an anxiousness to establish the 'credentials' of religiyeznavstvo as a rigorous academic subject, one in 
which methodological questions and interdisciplinary connections are accorded their due weight. ${ }^{17}$ This brings about the situation whereby opening lectures of courses bear considerably more weight and significance in the post-Soviet context than do the opening lectures of an equivalent course at a British institution. In both cases, postSoviet and British, students are being encouraged to reflect upon the scope of the subject and on the types of enquiry appropriate to it. However, the lecturer in Kiev, Moscow or Minsk may also perceive a need to justify the whole enterprise in ways that would not be necessary elsewhere. This 'justification' might amount to: (a) arguing that since religion exists as a phenomenon in our world, we need to study that phenomenon; (b) establishing the appropriateness of the methods or tools of enquiry; or (c) 'special pleading' for the atheist position that accompanies methodological and related considerations. If one is to judge by the description of Theme 1 of the religious studies course offered at the State Institute of Culture in Khar'kiv in the academic year 1992-3, one would have grounds for concluding that, in this case, the 'special pleading' element is present. The course description reads as follows:

\section{Theme 1: Religious studies as an academic subject ${ }^{18}$}

The subject of religious studies; religious studies: their place in the system of academic knowledge; the structure of academic religious studies; religious studies and theology; the methodological principles and apparatus of categories of religious studies; the history of research into the phenomenon of religion; free thought as a tendency in religious studies (svobodomysliye kak religiovedcheskoye napravleniye); principal forms of free thought; Ukrainian thought in the field of religious studies; principal tendencies in modern religious studies.

\section{Courses of Study in Denominational Institutions}

Among the denominational teaching institutions in Ukraine, the very nature of their principal task - that of training new generations of clergy - makes for a measure of continuity with pre-Soviet education. Their syllabuses contain most of the subject areas that we would expect them to contain. In numerous other ways these institutions encounter the same practical difficulties faced by the secular, non-denominational institutions, notably an acute shortage of books, inadequate buildings and students who are not used to academic discourse in the conditions of an open society.

The Theological Seminary of the Orthodox Church of the Moscow Patriarchate in Odessa was one of only three seminaries permitted to function during the Soviet period. Located right in the heart of the city until the 1960 s, it is now housed alongside the Uspensky Monastery, close to the shore of the Black Sea. In the present academic year there are 276 full-time resident students taught by a staff of 26 lecturers. Entry is by competitive examination and recommendation from the prospective candidate's parish, which may be in Ukraine, Russia or some other republic of the former Soviet Union. The age range is from 18 to 35 years. ${ }^{19}$

The subjects now studied at the Russian Orthodox Seminary in Odessa are as follows:

Biblical history

Old Testament Scripture

New Testament Scripture

Catechesis
Pastoral leadership

Christian denominations

Church singing

Greek 
Dogmatic theology

Fundamental theology

Moral theology

Comparative theology

Liturgy

Homiletics

General church history

History of the Russian church
Latin

English

French

German

Russian

Patristics

Iconography

Two further subjects are taught: the history of Ukraine and the history of Ukrainian literature both feature in the timetable, and these replace courses on the history of the USSR and the Constitution of the USSR.

In L'viv the Orthodox Church of the Kievan Patriarchate has a theological seminary which offers a four-year programme of study. Admission is by examination, and priority is given to candidates with previous higher education. ${ }^{20} \mathrm{Good}$ knowledge of the Ukrainian language is essential, as is at least a reading knowledge of Church Slavonic. The range of subjects studied is as one would expect to find within any establishment preparing ordinands for Christian ministry, and the teaching load is shared between 24 members of staff. In December 1993 the number of full-time resident students was 116 and the number of extramural students 65 . Financial and other practical difficulties, including the church jurisdictional conflict in Ukraine, had forced a very large number of seminarians to abandon their studies since the beginning of the academic year: the figures for September 1993 were 250 full-time students and 103 extramural students! ${ }^{21}$

The distribution of subjects through the working week is as follows:

First Year

$\begin{array}{ll}\text { Monday } & \text { Bible study } \\ & \text { Church rites } \\ & \text { Catechesis }\end{array}$

Wednesday Ukrainian language

Church singing

Ethics and aesthetics

Church rites

Friday Ukrainian literature

Church Slavonic

Church rites

$\begin{array}{ll}\text { Tuesday } & \begin{array}{l}\text { General church history } \\ \text { Biblical history } \\ \text { Catechesis }\end{array} \\ \text { Thursday } & \text { General church history } \\ & \text { Biblical history } \\ & \text { Catechesis } \\ \text { Church singing } & \text { Church Slavonic } \\ \text { Saturday } & \begin{array}{l}\text { Chistory of Ukraine } \\ \text { Church singing }\end{array}\end{array}$

Second Year

Monday Church rites

New Testament

Dogmatic theology

Patristics

Wednesday Church singing

Ukrainian language

History of the Orthodox

Church

Friday Old Testament

Ukrainian literature
Tuesday Old Testament

New Testament

General church history

Thursday Church rites

General church history

Dogmatic theology

Saturday Church singing

Church Slavonic 
Church Slavonic

History of Ukraine

Modern language options

Third Year

$\begin{array}{ll}\text { Monday } & \begin{array}{l}\text { Moral theology } \\ \text { Church rites } \\ \text { Old Testament } \\ \text { Christian denominations }\end{array} \\ \text { Wednesday } & \text { History of the Orthodox } \\ & \text { Church } \\ & \text { Moral theology } \\ & \text { Dogmatic theology } \\ & \text { Stylistics } \\ \text { Friday } & \text { Homiletics } \\ & \text { Church rites } \\ & \text { Ethics } \\ & \text { Dogmatic theology }\end{array}$

\author{
Tuesday History of the Orthodox \\ Church \\ General church history \\ Fundamental theology \\ Thursday Critical analysis of the Old \\ Testament \\ New Testament \\ General church history \\ Secular philosophy \\ Saturday Preparation for pastoral \\ ministry \\ Church singing \\ Modern language options
}

Final Year

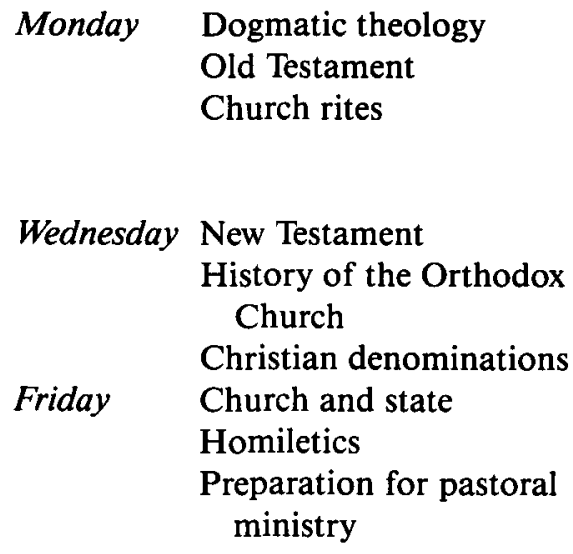

Thesday Apologetics

History of the Orthodox

Church

Dogmatic theology

Church singing

Thursday New Testament

Comparative theology

Church rites

Saturday Greek

Secular philosophy

Modern language options

Latin

Theological education and religious education generally are at the very centre of current activity in the Greek-Catholic dioceses in Western Ukraine as that community strives to utilise its new-found freedom. Two institutions in particular are concerned with theological education for ordinands and prospective teachers: the Theological Institute in Ivano-Frankivsk and the Theological Seminary of the Holy Spirit at Rudno outside L'viv. The number of full-time students at these establishments is $\mathbf{3 5 0}$ and 327 respectively, and the Seminary at Rudno actually had four applicants for every place. Rudno provides secondary level education, while the teaching in IvanoFrankivsk is pitched at tertiary level, with much emphasis placed upon teacher training. Those who attend the Theological Institute are required to teach in their parishes, schools or Sunday schools and to submit a record of their teaching activity in addition to taking examinations in theology. There are 20 lecturers on the Institute's teaching staff, who are also responsible for the tuition of students in a vast extramural department. 
The Theological Institute's course of study lasts six years, and the subject areas are distributed as follows:

First Year

Catechesis

Apologetics

History of Ukraine

A foreign language

Church rites

The foundations of asceticism

Church Slavonic

\section{Second Year}

Catechesis

The foundations of asceticism

Church Slavonic

History of Ukraine

Liturgical studies

Christian pedagogy

Biblical history of the Old Testament

History of philosophy

Church singing

\section{Third Year}

Liturgical studies

The foundation of asceticism

History of the Universal church

History of the church in Ukraine

Christian ethics

History of philosophy

\section{Fourth Year}

Moral theology

Pastoral theology

Dogmatic theology

Patristics

Christian denominations

Church singing

History of the Universal church

\section{Fifth Year}

Moral theology

Dogmatic theology

Patristics

Pastoral theology

Homiletics

Exegesis of the Epistles of the Holy Apostles
Introduction to the Bible

Church singing

Ukrainian language and its culture

Ukrainian literature

Logic

Introduction to philosophy

Latin

Greek

A foreign language

Ukrainian literature

Cosmology

Christian ethics

Exegesis of the Psalms

Introduction to philosophy

Biblical history of the New Testament

Latin

Greek

Church singing

Exegesis of the Old Testament

History of the church in Ukraine

The foundations of asceticism

Homiletics

Liturgical studies

History of philosophy

Exegesis of the New Testament

Hermeneutics

Liturgical studies

Church singing

Pastoral psychology

Documents of the Second Vatican Council History of Carpathia and of the GreekCatholic Church in Carpathia 
Sixth Year

Dogmatic theology

Moral theology

Liturgical studies

Canon law

Church singing

Documents of the Second Vatican Council
Church art and architecture

Pastoral psychology

Pastoral medicine

History of Carpathia and of the Greek-

Catholic Church in Carpathia

Plans are well advanced for the opening of a new Greek-Catholic theological academy in L'viv, which would be adapted to contemporary needs and might in time serve as the degree-awarding institution for the seminary at Rudno, once the academic level there has been raised.

Those concerned with the setting up of the theological academy look partly to the Catholic University of Lublin as a model, and they envisage an institution which will be strong in theology, philosophy and the liberal arts, with a particular emphasis upon competence in modern languages and in the languages required for sound philological work in theological textual analysis. ${ }^{22}$ There is a Commission for the Reestablishment of the Theological Academy of L'viv, headed by Dr Boris Gudzyak, ${ }^{23}$ which has set out its priorities. The Commission is concerned to provide an institution that will focus firmly upon study of the Bible, the Patristic tradition and the liturgical tradition.

Detailed syllabuses and projected courses of study already exist, but these do not fit within an article on teaching institutions active during the academic year 1993-4. However, the advanced state of the Commission's plans, which are oriented towards the following academic year and envisage a first intake of 30-40 students, clearly deserve mention. The ambitiousness of this enterprise might be gauged better when one considers that the Commission has plans for the setting up of five affiliated institutes, designed to develop particular areas of expertise. These are as follows:

Institute of Church History (already functioning)

Institute of Canon Law

Institute of the Family and Christian Marriage

Institute for Religious Education

Institute for Liturgy and Christian Culture. ${ }^{24}$

As far as the Evangelical Baptists in Ukraine are concerned, their religious education is at present being actively carried out at their Theological Seminary in Odessa and at their Bible College in Donetsk. The subject areas covered at the Bible College are as follows.

Department of Theology (three-year course of study)

Hermeneutics

Introduction to the Old Testament

Introduction to the New Testament

Missiology

Greek language and exegesis

Apologetics

Christian leadership

Evangelisation and the spiritual upbringing of children

Christian education

Pastoral service (parish placement)

Analytical study of books of the Old Testament 
Analytical study of books of the New Testament

Marriage and the family

Systematic theology

History of the Universal Church

History of the Russian church

History of the Evangelical Christian Baptists

Principles and methodology of teaching

English language

Evangelisation and the spiritual upbringing of young people

Department of Missiology (one-year course of study)

Hermeneutics

Introduction to the Old Testament

Introduction to the New Testament

Missiology

Apologetics

Christian leadership

Evangelisation and the spiritual upbringing of children

Christian education

Pastoral service (parish placement)

Homiletics

Systematic theology

History of the church

Spiritual life of the Christian believer

There is a further one-year course of study offered which includes nine of the above subject areas, but is specifically aimed at those who wish to learn radio broadcasting skills. The practical subjects in this course are as follows:

Introduction to means of communication

Introductory course on studio equipment

Producing scripts

Cross-cultural communication

Producing radio programmes

Variety of programme formats

Choice and use of music

Contact with the radio audience

Placement at a radio station

English language

\section{Conclusion}

This article sets out details of course structure and content for religious studies and related courses in a number of secular and denominational teaching institutions in Ukraine. It also states the present position regarding legislation on the separation of religion from state education (as set out in Article 6 of the Law on Freedom of Conscience and Religious Organisations), and illustrates various ways in which the term 'religious studies' - in Ukrainian religiyeznavstvo - is understood by some of those who teach the subject at tertiary level. Further, attention is drawn to the study of religion under the heading of kul'turologiya, that is cultural studies or the history of 
ideas. $^{25}$

This article does not treat religion as it is studied in departments of anthropology or ethnography, which would be likely to provide material for further articles, given that the study of religion was actively pursued in such departments during the Soviet period and that good conditions now exist for scholars in those fields to teach the subject freely. ${ }^{26}$

In the various syllabuses set out here, Ukrainian religious thought and cultural identity are prominent, as might be expected in a country that is engaged in the processes of growing independence and self-affirmation. It is noteworthy that the educational and ethical aspects of family life are promoted quite strongly: this is so in the Resolution of the Cabinet of Ministers of Ukraine, referred to in the first section of this article. More religious and explicitly Christian conceptions of the family feature in some of the syllabuses presented above, such as the school syllabus on Christian ethics being used in L'viv oblast' (see the beginning of the second section).

Family life and Christian upbringing are especially prominent in the courses offered by the Evangelical Baptists at their Bible College in Donetsk. At the Greek-Catholics' Theological Seminary of the Holy Spirit in Rudno, Fr Oleksander Kenez teaches a course on Christian marriage. It is particularly significant that one of the five planned institutes which will be affiliated to the Greek-Catholics' Theological Academy in L'viv is to be an 'Institute of the Family and Christian Marriage'. The diocesan secretary of the Orthodox diocese of Donetsk, Archimandrite Guri (Kuz'menko), observed that he and his fellow clergy frequently encounter people in their late thirties and forties who say: 'You may not be able to do very much for us in our generation, but please educate our children in the Christian way.'

Other aspects of religious education in contemporary Ukraine will be studied as the Leeds Research Project proceeds, with some focus on the non-Christian traditions.

\section{Notes and References}

1 A fuller statement of the objectives and scope of the Leeds Research Project may be found in The Bulletin of the Study Group on Education in Russia, the Independent States and Eastern Europe, vol. 11, no. 2, Autumn 1993, p. 74.

2 The 7 December 1993 issue of the newspaper Kiyevskiye vedomosti contains an interview with Petr Mikhailovich Talanchuk, Minister for Education, largely devoted to the Ukrainian government's plans for reforming the education system. Interestingly, the minister predicted that it might take ten to thirteen years for fundamental reform of the system to take effect. See Kiyevskiye vedomosti, 7 December 1993, p. 6 (interview conducted by Nataliya Bidnenko).

${ }^{3}$ Pro Derzhavnu natsional'nu programu 'Osvita' ('Ukraina XXI stolittya').

4 The word used in the syllabus here, and in other places, is dukhovny, which means 'spiritual', but also overlaps with 'cultural' in certain contexts. The noun is dukhovnost' (Ukrainian dukhovnyst').

5 I am particularly indebted to Professor Anatoli Vasil'yevich Yartis, Head of the Department of the Theory and History of Culture at Ivan Franko University in L'viv, for these figures and for much of the information about his own department.

6 Grigori Pomerants, author of Otkrytost' bezdne - Etyudi o Dostoevskom (New York, 1989) and Sny zemli (Paris, 1984), on the philosophy of history.

7 There are very slight abbreviations in this and following sections of the description of Theme 10.

${ }^{8}$ Shevchenko was in fact a Christian, though not denominationally inclined; Franko, although anticlerical, was not an atheist.

9 A very brief account of this and related courses at the Kiev-Mohyla Academy may be found 
in The Bulletin of the Study Group on Education in Russia, the Independent States and Eastern Europe, vol. 11, no. 2, Autumn 1993, p. 76. The seminar series on the Bible referred to in that article has been extended or restructured since the academic year 1992-3, with twelve seminars now on offer instead of five.

10 See Chapter 3 and other chapters of Michael Bourdeaux's Gorbachev, Glasnost and the Gospel (London, 1990) for a fuller chronology of the process, and on the particular impact of the Millennium celebrations, both at the official level and in society.

"Petro Mohyla was Orthodox Metropolitan of Kiev and All Rus' in the seventeenth century, and led a powerful Ukrainian intellectual renaissance. He is particularly remembered for the foundation of what came to be known as the 'Mohyla Academy', the first university-level institute of higher education in Ukraine, and the most important Orthodox theological school in the world at the time (since the Ottoman Turks did not permit Orthodox Christian theological schools in their dominions).

After the Moscow Patriarchate absorbed the Ukrainian Orthodox Church in the late seventeenth and early eighteenth centuries, the Mohyla Academy was closed, but its memory has always been an evocative image among Ukrainian intellectuals. With the achievement of Ukrainian independence in 1991, Ukrainian Christian educators of several denominations were able to gain possession of the Mohyla Academy building in Kiev and reopen the school (after a gap of nearly three centuries!), creating the first Christian University in Ukraine in modern times.

12 Those books of the Old Testament which do not fall under the headings of Law or the Books of the Prophets. They are more usually called 'the Writings'.

13 Donetsk is now a diocese in its own right, having until recently been part of the Diocese of Donetsk and Lutsk. It is an Orthodox diocese of the Moscow Patriarchate.

14 See Nauchny ateizm (Izdatel'stvo politicheskoi literatury, Moscow, 1988), $296 \mathrm{pp}$. The chapter headings in the textbook are as follows: 1, Religion as a socio-historical phenomenon; 2, Culture, religion and atheism; 3, The humanism of Marxist atheism; 4, Science versus religious conceptions; 5, Politics and religion: past and present; 6, Atheistic education: experience and problems.

15 Professor Kolodny informed me that even such practical and vocation-oriented establishments as institutes of ship construction (he cited the example of one such institute in Nikolayev near Odessa) have departments that teach religious studies.

16 At Moscow State University, in the Department of Russian Philosophy, staff were aware of the very considerable demand from students for courses on the major religious philosophers of the nineteenth and early twentieth centuries. Short courses devoted to their ideas were made available, but it was not at all clear that these one-term options were truly integrated into the work of the department offering them. (These observations are made on the basis of visits paid to that department in April 1993.)

17 In a period of flux, questions of methodology tend to assume particular importance as subject boundaries change and formerly prominent categories are replaced by others. Among the new philosophical journals to appear in Russia (as listed in Voprosy filosofii, no. 3, 1992, pp. 184-90) is one with the title Voprosy metodologii, edited by G. P. Shchedrovitsky. The heightened concern with methodology among scholars in post-Soviet society is being studied by Evert van der Zweerde of the University of Nijmegen, Netherlands, and increasingly, by myself.

18 Nauka, the Ukrainian or Russian word used here, has the meanings of 'science' and 'learning'. Here one is concerned with the status of religious studies as a bona fide academic subject, one that is approached with methodological precision akin to that which characterises the work of scientists.

19 Thanks are due to the Pro-Rector, Archimandrite Innokenti Shestopal', for all the information relating to the Orthodox Theological Seminary in Odessa.

20 Prospective candidates would also be expected to know by heart a considerable body of prayers, psalms and blessings and troparia for main Christian festivals and for their own Saint's day. 
21 If the proportion of students obliged to abandon their studies is this high at the Orthodox Seminary in L'viv, one must suppose that other teaching institutions in Ukraine are also affected by high 'drop-out' rates. However, I am not in a position to provide figures for other institutions.

22 Hebrew, Greek and Latin would be taught, as would Church Slavonic.

${ }^{23}$ Dr Gudzyak was born in the USA, studied theology in Rome and received his PhD from Harvard in 1992.

24 Information regarding the plans for the Theological Academy was kindly provided by Dr Boris Gudzyak, Chairman of the Commission responsible for this.

25 In the Russian Federation a leading institution in this field is the Institute of World Culture attached to the Faculty of Philosophy of Moscow State University. Its teaching staff includes scholars of world stature such as Sergei Averintsev, Renata Gal'tseva, Aleksandr Dobrokhotov and, until his recent death, Professor Yuri Lotman.

${ }^{26}$ See appendices to James Thrower's study Marxist-Leninist 'Scientific Atheism' and the Study of Religion and Atheism in the USSR (Mouton Publishers, Baton Rouge, 1983) for a survey of work in this field, including that by anthropologists and ethnographers. For a more recent account, see M. M. Shakhnovich's article 'The study of religion in the Soviet Union', Numen (Leiden), vol. 40, no. 1, 1993, pp. 67-81. 